\title{
HUBUNGAN TINGKAT PENGETAHUAN REMAJA \\ PUTRI TENTANG KANKER PAYUDARA DENGAN \\ SIKAP TERHADAP PEMERIKSAAN PAYUDARA \\ SENDIRI (SADARI) PADA SISWI KELAS II DI SMA \\ NEGERI 8 BATAM
}

\author{
Indah Mastikana
}

\begin{abstract}
ABSTRAK
Kanker payudara adalah pertumbuhan berlebihan atau perkembangan tidak terkontrol dari sel-sel dan jaringan payudara. Kanker payudara merupakan jenis kanker umum yang terjadi pada wanita oleh karena itu diharapkan seorang remaja mampu melakukan SADARI untuk mencegah kanker payudara sedini mungkin.

Penelitian ini merupakan penelitian Penelitian Kualitatif dengan desain penelitian bersifat Analitik, sampel yang diambil adalah sebanyak 115 siswi digunakan adalah Simple Random Sampling.

Hasil penelitian sebagian besar responden memiliki pengetahuan yang baik tentang kanker payudara dan besar responden mempunyai sikap yang kurang terhadap sadari dari hasil perhitungan Chi Square didapatkan nilai $\rho$-value sebesar 0,004 lebih kecil dibandingkan dengan nilai alpha $(0,004<0,05)$, artinya ada hubungan yang signifikan antara tingkat pengetahuan remaja putri tentang kanker payudara dengan sikap terhadap pemeriksaan payudara sendiri (SADARI).

Kesimpulan dari hasil penelitan dimana pengetahunan kanker payudara yang baik berhubungan dengan sikap pemeriksaan payudara sendiri (SADARI), sedangkan pengetahuan kanker payudara yang kurang sebagian besar tidak melakukan pemeriksaan payudara sendiri (SADARI). Oleh sebab itu hendaknya remaja putri mencari informasi tentang kanker payudara dan dapat mengaplikasikan pemeriksaan payudara sendiri untuk mencegah kanker payudara, bagi institusi kesehatan hendaknya mampu memberikan penyuluhan tentang kanker payudara.
\end{abstract}

Kata Kunci : Pengetahuan Remaja, Sikap Remaja, Kanker Payudara, SADARI

\section{PENDAHULUAN}

Kanker payudara adalah suatu penyakit dimana terjadi pertumbuhan kelebihan atau perkembangan yang tidak terkontrol dari sel-sel (jaringan) pada payudara. Kanker payudara
(Carcinoma

Mamaei)

didefinisikan sebagai suatu penyakit reoplasma yang ganas yang berasal dari parenchyma (Nugroho, 2011).

Kanker payudara tergolong kanker yang paling umum menyerang kaum wanita. 
Meskipun demikian, tidak menutup kemungkinan untuk menyerang kaum pria. Sampai saat ini, penyebab kanker payudara belum diketahui secara pasti, namun beberapa faktor yang memungkinkan menjadi penyebab kanker payudara adalah faktor usia, faktor genetik, pemakaian obat-obatan, dan stress juga termasuk salah satu penyebab kanker payudara (Aulia, 2012).

Beberapa hasil penelitian mengungkapkan bahwa resiko kanker payudara meningkat pada orang yang sering mengalami stress (goncangan jiwa) dan pada wanita yang mengalami menstruasi pertama di bawah usia 11 tahun (Aulia, 2012).

Berdasarkan data World Health Organization (WHO), jumlah penderita kanker payudara bertambah sekitar 7.000.000. Survey terakhir di dunia menunjukkan tiap tiga menit ditemukan penderita kanker payudara dan setiap 11 menit ditemukan satu orang wanita meninggal akibat kanker payudara (Batam Pos (2009, dalam Atika, 2010)).

Tahun 2000 diperkirakan 1 juta wanita terdiagnosis kanker payudara di seluruh dunia 67 sekitar 50 persen pasien mengalami kanker payudara metastatik dan hanya bertahan hidup 18 - 30 tahun (Merry Wahyuningsih, 2012).

Pada tahun 2008 tercatat 700.000 kasus kanker baru di negara-negara anggota ASEAN dan setengah juta kematian akibat kanker terjadi pada tahun yang sama. Pada tahun 2010 kanker merupakan salah satu penyebab utama kematian global dengan angka mencapai $13 \%$ (7,4 juta) dari semua kematian setiap tahunnya (Dewi Agustina, 2011).

Kanker payudara merupakan masalah kesehatan masyarakat yang penting. Menurut IARC, kanker payudara menempati urutan pertama berdasarkan insidennya dan kedua berdasarkan mortalitas kanker di dunia pada tahun 2008. Menurut ACS, terdapat 1,4 juta kasus baru kanker payudara (23\% dari semua kasus kanker) di dunia pada tahun 2008, yang setengahnya terjadi di negara berkembang. Bahkan, menurut WHO, mayoritas $(69 \%)$ kematian akibat kanker payudara terjadi di negara berkembang. WHO juga menyebutkan $8 \%-9 \%$ wanita akan mengalami kanker payudara semasa hidupnya. Bahkan, menurut survey terakhir, setiap tiga menit ditemukan penderita dan setiap 11 menit ditemukan seorang wanita meninggal akibat kanker payudara.

Sementara di Indonesia, rata-rata penderita kanker payudara adalah 10 dari 100.000 wanita (Batam Pos (2009, dalam Atika, 2010)). Di Indonesia, telah terjadi lonjakan luar biasa kasus kanker dalam 10 tahun terakhir, peringkat kanker sebagai penyebab utama kematian meningkat menjadi peringkat ke6 dari peringkat ke-12. Insiden kanker di Indonesia diperkirakan 180 per 100.000 penduduk. Data Sistem Informasi Rumah Sakit (SIRS) tahun 2004 - 2007 menunjukkan bahwakasus kanker payudara adalah jenis kanker tertinggi di Indonesia. Selain itu, kejadian kanker payudara di 
Indonesia meningkat sebesar $60 \%$ dari tahun 2004 hingga 2007.

Dari beberapa laporan, angka kanker payudara diperkirakan $20 \%$ dari seluruh kanker yang menyerang wanita, insidennya sekitar 100 penderita dari 100.000 jiwa per tahun, dan mortalitasnya sekitar $11,22 \%$ dari seluruh kejadian kanker. Berdasarkan data Registrasi Kanker, Sub Direktorat Kanker 2007, kanker payudara (32\%) merupakan jenis kanker tertinggi di 31 rumah sakit di DKI (Daerah Khusus Ibukota) Jakarta.

Survei yang dilakukan Yayasan Kesehatan Payudara Jakarta pada tahun 2005 menunjukkan $80 \%$ masyarakat tidak mengerti pentingnya pemeriksaan dini payudara. Sebanyak $70 \%$ kasus kanker payudara ditemukan dalam stadium lanjut sehingga angka kesintasannya rendah. Hal ini dikarenakan masih rendahnya kesadaran, pengertian, dan pengetahuan masyarakat tentang kanker payudara, sementara penanganan kanker payudara secara lintas sektoral belum mendapat prioritas dari pemerintah sebagian penderita kanker payudara di Indonesia ada yang baru berusia 18 tahun.

Data dari Jakarta Breats Center, Klinik di Jakarta yang mengkhususkan diri untuk penanganan keluhan pada payudara, menunjukan bahwa 2.495 pasien yang datang pada tahun 2001 - 2002, ternyata 79 persen menderita tumor jinak dan hanya 14 persen yang menderita kanter (Pamungkas, 2012).

Data yang dihimpun Yayasan Kesehatan Payudara
Jakarta menyebutkan banyak penderita kanker payudara pada usia relative muda. Bahkan, tidak sedikit remaja putri usia 14 tahun menderita tumor di payudara. Hal ini tentu saja sangat menyedihkan dan mengenaskan.

Penelitian medis sampai saat ini masih belum dapat memastikan penyebab kanker payudara. Namun dari jumlah penderita yang terus meningkat dari tahun ke tahun. Data dari Rumah Sakit Awal Bros Batam mencatat sekitar 40 penderita kanker payudara dan di Rumah Sakit Permata Hati ditemukan satu kasus Dalam setahun. Dalam seminar kanker payudara dan resikonya di Rumah Sakit Awal Bross. Dalam seminar kanker payudara dan resikonya di Rumah Sakit Awal Bross, Spesialis mengatakan langkah-langkah mengetahui ancaman penyakit mematikan ini, yaitu melalui "SADARI" atau pemeriksaan payudara sendiri (Batam Pos (2009, dalam Atika, 2010)).

Pemeriksaan payudara secara rutin sangat diperlukkan untuk mendeteksi adanya kanker atau tumor pada payudara sedini mungkin. Hal ini terutama bagi kaum perempuan yang memiliki resiko tinggi terkena kanker payudara. Semakin dini kanker tersebut ditemukan dan segera ditangani, akan memberikan harapan kesembuhan dan harapan hidup yang semakin besar (Luwia, 2003). Melakukan pemeriksaan payudara sendiri (SADARI) ini adalah pemeriksaan yang mudah dilakukan oleh setiap wanita untuk mencari benjolan atau 
kelainan lainnya (Dalimartha, 2004).

Berdasarkan wawancara yang dilakukan pada Mei 2016 terhadap 5 siswi SMA Negeri 8 Batam, 2 diantaranya mengetahui tentang kanker payudara dan seluruhnya tidak mengetahui bagaimana cara melakukan

SADARI.

\section{METODE}

Jenis penelitian ini merupakan penelitian Penelitian Kualitatif. dengan metode pengumpulan data Cross sectional

Populsi (universe) adalah keseluruhan unit analisis yang karakteristiknya akan diduga (Hastono \& Lubis, 2010).

Populasi dalam penelitian ini ada Seluruh Remaja Putri SMA Negeri 8 Bengkong, Batam Kelas II yaitu 294 siswi.

Sampel adalah sebagaian populasi yang ciri-cirinya diselidiki atau diukir (Hastono \& Sabri, 2010).

Jadi, jumlah sample yang diambil adalah sebanyak 115 siswi kelas II SMA Negeri 8 Bengkong, Batam. Maka penarikan sample yang digunakan adalah Simple Random Sampling yaitu dilakukan secara acak tanpa memperhatikan strata yang ada, setiap subjek/ unit populasi memiliki peluang yang sama dan independen (tidak tergantung) untuk terpilih kedalam sample (Sulistyaningsih, 2011).

Teknik Pengumpulan Data
dalam penelitian ini
menggunakan data primer.
Pengumpulan data primer yakni

menggunakan data yang berasal dari sumber asli atau pertama. Data primer didapatkan dengan cara menyebarkan kuesioner kepada responden.

Uji analisis untuk mengukur hubungan antara variabel dependent dengan variabel independent dalam hal adalah pengetahuan remaja putri dan sikap terhadap SADARI. menggunakan uji statistitik $C h i$ Square.

\section{HASIL}

Analisa Univariat

5.1.1.Hasil

Analisa

Univariat

a. Distribusi frekuensi

Pengetahuan remaja

tentang kanker payudara pada siswi kelas II di SMA Negeri 8 Batam Tahun 2016 dilihat pada tabel sebagai berikut:

Dari tabel 5.1 di atas menunjukkan bahwa dari 80 remaja putri lebih banyak berpengetahuan baik sebanyak 44 orang (55\%) dibandingkan dengan pengetahuannya kurang sebanyak orang 36 orang $(45 \%)$.

b. Distribusi frekuensi sikap terhadap pemeriksaan payudara sendiri (SADARI) pada siswi kelas II di SMA Negeri 8 Batam Tahun 2016 dapat dilihat pada tabel sebagai berikut:

Dari tabel 5.2 di atas menunjukkan bahwa dari 80 remaja putri, lebih banyak sikap kurang terhadap pemeriksaan payudara sendiri (SADARI) sebanyak 47 


\author{
orang \\ $(58.8 \%)$ \\ dibandingkan sikap baik \\ terhadap pemeriksaan \\ payudara sendiri \\ (SADARI) sebanyak 33 \\ orang $(41,2 \%)$.
}

\section{Analisa Bivariat}

Hasil analisis bivariat bertujuan untuk mengetahui hubungan tingkat pengetahuan remaja putri tentang kanker payudara dengan sikap terhadap pemeriksaan payudara sendiri (SADARI) pada siswi kelas II di SMA Negeri 8 Batam Tahun 2016.

a.

$\begin{array}{lr}\text { Distribusi } & \text { frekuensi } \\ \text { hubungan } & \text { tingkat } \\ \text { pengetahuan } & \text { remaja putri }\end{array}$

tentang kanker payudara

dengan sikap terhadap

pemeriksaan payudara

sendiri (SADARI) pada siswi kelas II di SMA

Negeri 8 Batam Tahun 2016 dapat dilihat pada tabel sebagai berikut:

b. Dari tabel 5.3 diatas menunjukkan bahwa hasil penelitian Remaja putri memiliki pengetahuan yang baik tentang kanker payudara dan mempunyai sikap yang baik terhadap pemeriksaan payudara sendiri (SADARI) sebanyak 25 responden (56.8\%), remaja putri yang memiliki pengetahuan yang baik terhadap kanker payudara dan mempunyai sikap yang kurang terhadap pemeriksaan payudara sendiri (SADARI) sebanyak 19 responden (43.2\%), remaja putri yang memiliki pengetahuan kurang terhadap kanker payudara dan mempunyai sikap yang baik terhadap pemeriksaan payudara sendiri (SADARI) sebanyak 8 responden $(22.2 \%)$, remaja putri yang mempunyai pengetahuan kurang terhadap kanker payudara dan mempunyai sikap yang kurang terhadap pemeriksaan payudara sendiri (SADARI) sebanyak 28 responden $(77.8 \%)$.

c. Dari hasil perhitungan $C h i$ Square didapatkan nilai $\rho$ value sebesar 0.004 , karena hasil $\rho$-value $<0,05$ berarti $\mathrm{H}_{\mathrm{a}}$ terima $\mathrm{H}_{0}$ ditolak, maka dapat disimpulkan bahwa ada hubungan yang signifikan antara hubungan tingkat pengetahuan remaja putri tentang kanker payudara dengan sikap terhadap pemeriksaan payudara sendiri (SADARI).

\section{PEMBAHASAN}

Hubungan tingkat pengetahuan remaja putri tentang kanker payudara dengan sikap terhadap pemeriksaan payudara sendiri (SADARI).

Berdasarkan hasil penelitian dari 80 remaja putri pengetahuan yang baik dan mempunyai sikap yang baik sebanyak 25 responden $(56.8 \%)$, remaja putri yang memiliki pengetahuan yang baik dan mempunyai sikap yang kurang sebanyak 19 responden (43.2\%), Remaja putri yang memiliki pengetahuan kurang dan sikap yang baik sebanyak 8 responden $(22.2 \%)$, remaja putri yang mempunyai pengetahuan 
kurang dan sikap kurang sebanyak 28 responden (77.8\%).

Dari hasil perhitungan $C h i$ Square didapatkan nilai $\rho$-value sebesar 0,004 ini meenandakan bahwa nilai $\rho$-value lebih kecil dibandingan dengan nilai alfa $(0,004<0,05)$, dengan demikian dapat disimpulkan secara statistik, $\mathrm{H}_{\mathrm{a}}$ diterima Ho ditolak, bahwa ada hubungan yang signifikan antara hubungan tingkat pengetahuan remaja putri tentang kanker payudara dengan sikap terhadap pemeriksaan payudara sendiri (SADARI).

Hasil penelitian ini sejalan dengan hasil studi yang dilakukan WHO dan para ahli pendidikan kesehatan, terungkap memang benar bahwa pengetahun masyarakat tentang kesehatan sudah tinggi, tetapi praktik mereka masih rendah. Hal ini berarti bahwa perubahan atau peningkatan pengetahuan masyarakat tentang kesehatan sudah tinggi, tetapi prilakunya masih rendah. Hal ini berarti bahwa perubahan atau peningkatan pengetahuan masyarakat tentang kesehatan tidak diimbangi dengan prilakunya.

Hasil penelitian diatas tidak sejalan dengan tinjauan teori yang menyebutkan bahwa sikap dan prilaku didasari oleh pengetahuan akan lebih langgeng dari pada perilaku dan sikap yang tidak didasari oleh pengetahuan.

\section{KESIMPULAN}

Berdasarkan hasil penelitian dan pengolahan data yang telah dilaksanakan oleh peneliti mengenai hubungan tingkat pengetahuan remaja putri tentang kanker payudara dengan sikap terhadap pemeriksaan payudara sendiri (SADARI) pada siswi kelas II di SMA Negeri 8 Batam Tahun 2016, dapat disimpulkan bahwa:

6.1.1 Pengetahuan remaja putri tentang kanker payudara yaitu yang pengetahuannya baik sebanyak 44 orang (55\%) dan yang pengetahuannya kurang sebanyak orang 36 orang (45\%)

6.1.2 Sikap remaja putri terhadap pemeriksaan payudara sendiri (SADARI) baik sebanyak 33 orang $(41,2 \%)$ dan yang kurang sebanyak 47 orang $(58.8 \%)$.

6.1.3 Ada hubungan yang signfikan antara tingkat pengetahuan remaja putri tentang kanker payudara dengan sikap terhadap pemeriksaan payudara sendiri (SADARI) dimana diperoleh $\rho$-value sebesar $0,004(\rho$-value $<0,05)$

\section{SARAN}

6.1.1 Bagi Peneliti Agar penelitian yang dilakukan ini dapat menambah wawasan dan informasi kepada peneliti mengenai bagaimana hubungan kanker payudara dengan pemeriksaan sadari.

6.1.2 Bagi Tempat Peneliti Disarankan kepada tempat agar dapat memberikan informasi tentang pentingnya sadari untuk mencegah kanker payudara. Meliputi pengertian, keuntungan, 
kekurangan, indikasi, dan kontraindikasi.

6.1.3 Bagi Institusi Pendidikan Hasil penelitian ini dapat digunakan untuk dapat menjadi bahan masukan, pertimbangan serta perbandingan bagi peneliti yang serupa dikemudian hari dan dapat membantu dalam proses pembelajaran.

6.1.4 Bagi Masyarakat

Hasil penelitian ini di harapkan agar masyarakat dapat lebih mengenal luas tentang kanker payudara dan penanganan untuk mencegah payudara.

\section{DAFTAR PUSTAKA}

Arikunto, Prof. Dr. Suharsini, 2006. Prosedur Penelitian Suatu Tindakan Praktik (Edisi Revisi VI): Jakarta, Rineka Cipta

Atika, Gambaran Pengetahuan Wanita Usia Subur Tentang Sadari Dan Cara Melakukan Deteksi Dini Kanker Payudara, Batam: 2010

Aulia, 2012. Serangan PenyakitPenyakit Khas Wanita Paling Sering Terjadi: Jogjakarta, Buku Biru.

Chandra,Dr. Budiman, 2008. Metodologi Penelitian Kesehatan: Jakarta, Buku kedokteran EGC.
Dahlan, M. Sopiyudin, 2009.

Statistik untuk kedokteran

dan kesehatan,edisi 4:

Jakarta, Salemba Medika.

Dalimartha, S. 2004. Deteksi Dini Kanker Dan Simplisi Anti Kanker: Jakarta, Penebar Swadaya.

Hastono, Susanto Prio \& Luknis Sabri, 2010. Statistik Kesehatan: Jakarta, Rajawali Pers.

Hidayat, A. Aziz Alimul, 2010. Metode Penelitian Kebidanan Teknik Analisis Data: Jakarta, Salemba Medika

Luwia, M. 2003. Problematika Dan Perawatan Payudara: Jakarta, Kawan Pustaka.

Lenggogeni, putri, Faktor-Faktor Yang Berhubungan Dengan Deteksi Dini Kanker Payudara Melalui Pemeriksaan Payudara Sendiri Oleh Mahasiswi Jalur Program Studi Ilmu Kesehatan Masyarakat Fakultas Kedokteran UNAND, Padang: 2011 